\title{
Jaminan Fidusia dalam Pembiayaan Murabahah: antara Jual Beli dan Hutang Piutang
}

\author{
Nur Hidayah ${ }^{1}$, Moch. Bukhori Muslim², Abdul Azis ${ }^{3 *}$ \\ Universitas Islam Negeri Syarif Hidayatullah Jakarta \\ Jl. Ir. H. Juanda No. 95, Ciputat Timur, Kota Tangerang Selatan, Banten \\ Email:1nurhidayah@uinjkt.ac.id; ${ }^{2 b u k h o r i . m u s l i m @ u i n j k t . a c . i d ; 3^{*} a a z i s 99 @ g m a i l . c o m ~}$
}

\begin{tabular}{llll}
\hline Submit & $: 21$ Agustus 2021 & Diterima & $: 5$ Oktober 2021 \\
Revisi & $: 15$ November 2021 & Terbit & $: 1$ Desember 2021 \\
\hline
\end{tabular}

\begin{abstract}
The issue of shifting from sale and purchase transactions to service transactions due to the binding of collateral with mortgage or fiduciary rights can become a transaction that is null and void. Solving legal issues related to how the concept of binding collateral needs to be seen in an ontological and philosophical scope. The binding of collateral on murabahah financing should be based on the existence of customer obligations for purchases that have not been paid off based on the Sharia Banking Law. The binding of collateral on murabahah transactions can also be carried out with mortgage rights or fiduciary guarantees based on the existence of customer obligations for purchases that have not been paid off as guided by the Mortgage Law and the Fiduciary Guarantee Law which has accommodated the binding of collateral by basing other main agreements other than the main agreement due to accounts payable.
\end{abstract}

Keywords: collateral, obligations, not paid off, principal agreement, debt.

Abstrak: Isu pergeseran dari transaksi jual beli menjadi transaksi jasa karena pengikatan agunan dengan hak tanggungan atau fidusia, dapat menjadi transaksi yang batal demi hukum. Pemecahan isu hukum terkait bagaimana konsep pengikatan agunan perlu dilihat pada ruang lingkup ontologis dan filosofis. Pengikatan agunan pada pembiayaan murabahah seharusnya didasarkan adanya kewajiban nasabah atas pembelian yang belum lunas berpedoman pada Undang-Undang Perbankan Syariah. Pengikatan agunan pada transaksi murabahah juga dapat dilakukan dengan hak tanggungan atau jaminan fidusia dengan mendasarkan adanya kewajiban nasabah atas pembelian yang belum lunas sebagaimana berpedoman pada Undang-Undang Hak Tanggungan dan Undang-Undang Jaminan Fidusia yang telah mengkomodir pengikatan agunan dengan mendasarkan perjanjian pokok lainnya selain perjanjian pokok karena utang piutang.

Kata kunci: agunan, kewajiban, belum lunas, perjanjian pokok, utang.

\section{Pendahuluan}

Pengikatan agunan pada pembiayaan murabahah pada umumnya masih bertumpu atas hutang yang belum lunas yang berpedoman pada Undang-Undang Hak Tanggungan dan Undang-Undang Jaminan Fidusia. Pengikatan agunan telah diatur khususnya pada Undang-Undang Hak Tanggungan untuk menjamin pelunasan utang, dan diatur pula pada Undang-Undang Jaminan Fidusia juga sebagai 
agunan untuk pelunasan utang tertentu. Agunan untuk perbankan telah diatur pada Undang-Undang Perbankan perubahan tahun 1999 sebagai jaminan tambahan dalam rangka pemberian fasilitas kredit atau pembiayaan berprinsip syariah. Agunan pada Undang-Undang Perbankan Syariah sebagai jaminan tambahan untuk menjamin pelunasan kewajiban nasabah penerima fasilitas dari perbankan yang belum lunas.

Undang-Undang Perbankan terkait agunan sedikit banyak masih meminta untuk memerhatikan Undang-Undang Hak Tanggungan, sedangkan Undang-Undang Perbankan Syariah sama sekali tidak menyinggung terkait Undang-Undang Hak Tanggungan maupun Undang-Undang Jaminan Fidusia.

Agunan pada pembiayaan murabahah dilakukan untuk menjamin pemesanan nasabah atau untuk menjamin pelunasan kewajiban nasabah penerima fasilitas pembiayaan yang belum lunas. Bank dapat meminta kepada nasabah untuk menyediakan agunan atas pesanan nasabah, yang di antara tujuan adanya agunan adalah agar nasabah serius dengan pesanannya. Pada pembiayaan murabahah, permintaan uang muka kepada nasabah pemesan dapat dikategorikan sebagai agunan atas nasabah serius. ${ }^{1}$ Ketentuan Fatwa DSN MUI diperjelas oleh KHES yaitu uang muka harus diserahkan oleh nasabah kepada bank sesaat ketika nasabah menandatangani pemesanan obyek murabahah. ${ }^{2}$

Maksudadanyauang muka pada pembiayaan murabahah agar nasabah memiliki keseriusan dalam memesan obyek, dan uang muka diserahkan kepada bank sesaat ketika nasabah menandatangani pemesanan obyek dan penyerahan uang muka tidak kepada suppier, uang muka nantinya dijadikan sebagai bagian dari pembayaran nasabah kepada bank apabila pembiayaan berlanjut, namun apabila pembiayaan tidak dapat berlanjut maka uang muka dikembalikan kepada nasabah dengan dilakukan pengurangan apabila bank mengalami kerugian akibat pemesanan obyek oleh nasabah. ${ }^{3}$

Klausulyang ditandatangani nasabah padasaat pemesanan barang di antaranyabank memberikan kuasa kepada nasabah untuk melakukan pembelian langsung kepada supplier, pencatatan pembelian langsung diatas-namakan nasabah, nasabah menerima penyerahan barang secara langsung dari supplier, nasabah menanggung dan membayar sendiri segala kerugian dan beban terkait pembelian obyek. Pengikatan agunan dengan hak tanggungan atau jaminan fidusia dapat dilakukan langsung pada saat pemesanan obyek, dan pengikatan agunan tersebut dapat berlanjut dan tidak perlu diulangi lagi apabila transaksi pembiayaan murabahah jadi dilaksanakan. Hak tanggungan atau jaminan fidusia akan digunakan sebagai pelunasan pembayaran nasabah apabila pembayaran nasabah gagal bayar. $^{4}$

Penelitian ini untuk menjawab bagaimana pengikatan agunan menjadi penyebab pembiayaan murabahah bergeser dari transaksi jual beli menjadi transaksi jasa, yang dilakukan dengan cara menganalisa terhadap dasar ontologis dilakukan dengan pendekatan filosofis normatif, terhadap dasar ratio legis dilakukan dengan pendekatan yuridis normatif, dan terhadap fakta-fakta hukum dilakukan dengan pendekatan yuridis empiris. Selain analisa juga dilakukan Interpretasi secara

1 Fatwa Dewan Syariah Nasional Majelis Ulama Indonesia tentang Murabahah No.04/DSN-MUI/IV/2000, lihat pula pada Peraturan Mahkamah Agung RI tentang Kompilasi Hukum Ekonomi Syariah, Pasal 122, Pasal 123.

2 Mahkamah Agung RI, Peraturan Kompilasi Hukum Ekonomi Syariah, Pasal 121, Pasal 127.

3 PT BPRS Puduarta Insani, Jual beli murabahah, 10 Oktober 2018, dari http://ptbprspuduartainsani.com/halaman /jual-belimurabahah.

4 Wawancara dengan Hamza Marasabessy, Karyawan BNI Syariah Ambon, 8 April 2020 melalui media whatsapp, yang hasilnya dibenarkan sebagaimana berdasarkan Wawancara pribadi dengan Rudi Widodo, Kepala Sub Bagian Pengembangan Perbankan Syariah Sektor Jasa Keuangan Otoritas Jasa Keuangan RI, 15 Juli 2020 melalui media telepon. 
sistematis terhadap hubungan aturan-aturan dalam suatu undang-undang yang saling bergantung dengan asas-asas yang melandasinya, dilakukan interpretasi secara historis terhadap aturan-aturan dengan dilacak dari segi lahirnya, dan dilakukan interpretasi secara teleologis yaitu terhadap tujuan adanya aturan-aturan, terhadap pemikiran yang melandasinya, dan terhadap penjelasan rasional untuk apa aturan-aturan itu dibuat. ${ }^{5}$

\section{Agunan Murabahah: Antara Transaksi Jual Beli dan Transaksi Jasa}

Isu pergeseran dari transaksi jual beli menjadi transaksi jasa karena pengikatan agunan dengan hak tanggungan atau fidusia, dapat menjadi transaksi yang batal demi hukum. Hal ini sebagai akibat dari pengikatan agunan dengan hak tanggungan atau jaminan fidusia yang mendasarkan pada utang sebagai akibat pembayaran secara angsuran, sehingga adanya utang tidak terkait dengan fasilitas pembiayaan dan tidak ada keterkaitan dengan akad jual beli murabahah melainkan adanya utang yang berdiri sendiri sebagai akad utang piutang.

Pemecahan isu hukum terkait bagaimana konsep pengikatan agunan perlu dilihat pada ruang lingkup ontologis dan filosofis. Konsep ontologis dan filosofis hak tanggungan yang dapat dilihat pada penjelasan umum dan konsideran menimbang pada Undang-Undang Hak Tanggungan menjelaskan bahwa agunan khususnya atas tanah mengutamakan atau mendahulukan pemegang hak, agunan mengikuti obyek yang dijaminkan, mengikat pihak ketiga dan memberikan kepastian hukum bagi pemegang hak, dapat dieksekusi. Pejabat Pembuat Akta Tanah (PPAT) khususnya terkait agunan tanah, dalam membuat akta tetap mengikuti wilayah hukum PPAT yaitu di mana obyek agunan berada. Dalam pemberian hak tanggungan wajib hadir di hadapan PPAT atau menunjuk pihak lain sebagai kuasanya dengan surat kuasa yang berbentuk akta otentik yang dibuat oleh notaris atau PPAT yang berwenang. Pencatatan adanya pengikatan hak tanggungan dilakukan pada buku tanah dan pada sertipikat hak atas tanah yang dijadikan agunan. Penghapusan hak dilakukan dengan cara mencoret hak tersebut dan membubuhkan catatan mengenai hapusnya hak tersebut pada buku tanah dan sertifikat hak atas tanah tersebut. Hak Tanggungan adalah aksesoris dari adanya piutang tertentu berdasarkan perjanjian utang piutang yang dijamin pelunasannya atau perjanjian lainnya. ${ }^{6}$ Perlunya lembaga penjaminan untuk memberikan kepastian hukum bagi para pihak yang berkepentingan, supaya cita-cita pembangunan untuk masyarakat sejahtera dapat terpenuhi. Hak-hak atas tanah baik berupa hak milik, hak guna bangunan, hak guna usaha, hak pakai dapat dibebani hak tanggungan. ${ }^{7}$

\section{Ruang Lingkup Filosofis Normatif}

Konsep ontologis dan filosofis jaminan fidusia yang dapat dilihat pada penjelasan umum dan konsideran menimbang pada Undang-Undang Jaminan Fidusia menjelaskan bahwa Jaminan fidusia di antaranya untuk memenuhi kebutuhan dan menjamin kepastian hukum, perlu juga dibentuk kantor pendaftaran fidusia. Jaminan fidusia lahir dari yurisprudensi, dan jaminan fidusia telah ada

5 Peter Mahmud Marzuki, Penelitian Hukum Normatif: Edisi Revisi (Jakarta: Kencana, 2017), 136-157.

6 Undang-Undang No. 4 Tahun 1996 tentang Hak Tanggungan atas Tanah Beserta Benda-Benda yang Berkaitan dengan Tanah, LN No. 42 Tahun 1996, TLN No.3632, Penjelasan Umum, khususnya angka 8 yang menjelaskan Oleh karena Hak Tanggungan menurut sifatnya merupakan ikutan atau accessoir pada suatu piutang tertentu, yang didasarkan pada suatu perjanjian utangpiutang atau perjanjian lain, maka kelahiran dan keberadaannya ditentukan oleh adanya piutang yang dijamin pelunasannya.

7 Undang-Undang No. 4 Tahun 1996, Konsideran Menimbang. 
di Indonesia sejak zaman penjajahan Belanda. ${ }^{8}$ Jaminan fidusia yang dapat diberikan di antaranya berupa benda bergerak yang berwujud maupun tak berwujud, benda tidak bergerak yang tidak dapat dibebani dengan hak tanggungan. Perlunya pendaftaran jaminan fidusia untuk memberikan kepastian hukum kepada penerima fidusia dan pihak yang mempunyai kepentingan terhadap benda tersebut. ${ }^{9}$

Konsep ontologis dan filosofis pengikatan agunan yang dapat dilihat pada penjelasan umum dan konsideran menimbang pada Undang-Undang Perbankan Syariah menjelaskan bahwa bank dalam memberikan fasilitas pembiayaan, tentunya harus menilai obyek agunan apakah penjualan agunan nantinya sudah mencukupi apabila nasabah tidak dapat melunasi kewajibannya. ${ }^{10}$

Pada dasar ontologis dan filosofis telah dijelaskan bahwa hak tanggungan telah dimaknai secara luas yaitu tidak hanya berlaku untuk menjamin pelunasan adanya utang piutang akan tetapi hak tanggungan juga menjamin pelunasan adanya perjanjian lainnya yang dalam hal ini dapat dimaknai untuk menjamin pelunasan karena kewajiban nasabah yang belum lunas. Pada dasar ontologis dan filosofis jaminan fidusia juga telah dimaknai secara luas sejak Indonesia belum merdeka dan jaminan fidusia lahir dari yurisprudensi, yang dapat ditafsirkan bahwa jaminan fidusia dapat berlaku untuk menjamin pelunasan adanya perjanjian lainnya yang dalam hal ini dapat dimaknai untuk menjamin pelunasan karena kewajiban nasabah yang belum lunas.

Menjelaskan keberadaan jaminan fidusia, Mahkamah Konstitusi RI pada pertimbangan hukumnya mendalilkan bahwa jaminan fidusia dapat dimaknai karena suatu perjanjian yang tidak hanya karena perjanjian utang piutang akan tetapi jaminan fidusia berlaku untuk perjanjian lainnya, yang dapat dimaknai bahwa jaminan fidusia dapat berlaku untuk menjamin pelunasan karena kewajiban nasabah yang belum lunas. ${ }^{11}$ Perjanjian lain dapat dimaksudkan juga sebagai perjanjian pembiayaan pada perbankan syariah seperti perjanjian pembiayaan murabahah, di mana jaminan fidusia untuk menjamin pelunasan kewajiban nasabah penerima fasilitas pembiayaan yang belum melunasi kewajibannya untuk melakukan pelunasan pembayaran pembelian obyek pembiayaan kepada pihak bank baik pelunasan pembayaran secara angsuran atau secara seketika.

Dengan demikian, dasar ontologis dan filosofis khususnya pada Undang-Undang Hak Tanggungan dan Undang-UndangJaminan Fidusia dapat disimpulkan telah mengakomodir perjanjian pembiayaan perbankan syariah khususnya transaksi murabahah yang merupakan transaksi jual beli, yang dapat dikategorikan sebagai perjanjian lain selain perjanjian utang piutang.

Hak tanggungan dan/atau jaminan fidusia seharusnya tetap diposisikan sebagai aksesoris dari adanya perjanjian pokok yang dalam hal ini khususnya pembiayaan murabahah tidak dalam kapasitas membenarkan atau tidak membenarkan adanya pelaksanaan jual beli pada pembiayaan murabahah, melainkan kedudukan hak tanggungan dan/atau jaminan fidusia tetap harus tunduk pada ketentuan hukum pelaksanaan jual beli pada pembiayaan murabahah yaitu adanya pengikatan agunan untuk

8 Undang-Undang No. 42 Tahun 1999 tentang Jaminan Fidusia, LN No.168 Tahun 1999, TLN No.3889, Penjelasan Umum.

9 Undang-Undang No. 42 Tahun 1999, Konsideran Menimbang.

10 Undang-Undang No. 21 Tahun 2011 tentang Perbankan Syariah, Penjelasan Umum.

${ }^{11}$ Mahkamah Konstitusi RI, Putusan Pengujian Undang-Undang,PUU No. 18/PUU-XVII/2019 tanggal 6 Januari 2020, halaman 114-115 angka 3.12 poin 3 yang menjelaskan bahwa jaminan fidusia merupakan perjanjian yang bersifat accesoir dengan perjanjian utamanya yang artinya bahwa perjanjian pokoknya adalah berupa perjanjian pinjam-meminjam atau perjanjian lain yang dapat dinilai dengan uang sepanjang yang menjadi objek perjanjian fidusia adalah benda bergerak, baik berwujud atau tidak berwujud maupun benda tidak bergerak khususnya bangunan yang tidak dapat dibebani hak tanggungan. 
menjamin pelunasan kewajiban nasabah yang belum lunas. Adanya pengikatan agunan pada pembiayaan murabahah tidak seharusnya dimaknai adanya pengikatan agunan untuk pelunasan utang yang timbul dari transaksi pembiayaan murabahah, karena maksud adanya kalimat pelunasan utang adalah sebagai perjanjian pokok yaitu perjanjian utang piutang dan telah menjadikan penyebab pembiayaan murabahah bergeser dari transaksi jual beli menjadi transaksi jasa.

\section{Ruang Lingkup Yuridis Normatif}

Pemecahan isu hukum terkait bagaimana konsep pengikatan agunan perlu dilihat pada ruang lingkup ratio legis. Konsep ratio legis pada hak tanggungan sebagaimana yang telah dituangkan pada Undang-Undang Hak Tanggungan menjelaskan bahwa hak tanggungan dapat diartikan sebagai hak jaminan yang dibebankan pada hak atas tanah berikut atau tidak berikut benda-benda diatas/ didalamnya untuk pelunasan utang tertentu, dengan mengutamakan kreditor tertentu terhadap kreditor-kreditor lain. Utang yang dijamin pelunasannya dapat berupa utang yang telah ada, utang yang belum ada tetapi telah diperjanjikan, dan biaya-biaya lain yang nilainya akan ditentukan kemudian. Akta pemberian hak tanggungan dibuat oleh PPAT. Dalam hal pemberi hak tanggungan ingkar janji, pemegang hak tanggungan mempunyai hak untuk menjual obyek hak tanggungan berdasarkan janji yang diberikan oleh pemberi hak tanggungan baik penjualan melalui pelelangan umum atau penjualan lelang melalui bantuan pengadilan untuk mengambil pelunasan piutangnya dari hasil penjualan lelang tersebut, dan penjualan lelang tersebut tidak memerlukan persetujuan dari pemberi hak tanggungan. Apabila hasil lelang terdapat sisa, maka sisanya menjadi hak pemberi hak tanggungan. Penjualan juga dapat dilakukan dengan di bawah tangan atas kesepakatan pemberi dan pemegang hak tanggungan untuk memperoleh harga tertinggi. Pemegang hak tanggungan dilarang secara serta merta menjadi pemilik obyek hak tanggungan karena pemberi hak tanggungan melakukan ingkar janji atau wanprestasi. ${ }^{12}$

Hak tanggungan selain untuk menjamin pelunasan utang tertentu yang timbul dari perjanjian utang piutang, hak tanggungan juga menjamin perjanjian lain yang menimbulkan hubungan hukum tertentu untuk melunasi kewajibannya. Konsep perjanjian lain pada hak tanggungan sebagaimana yang telah dituangkan pada Undang-Undang Hak Tanggungan secara khsusus pada Pasal 3 dan Pasal 10 beserta penjelasannya. ${ }^{13}$ Begitu juga Mahkamah Konstitusi RI telah memberikan penjelasan secara

${ }^{12}$ Undang-Undang No. 4 Tahun 1996 tentang Hak Tanggungan Atas Tanah Beserta Benda-Benda Yang Berkaitan Dengan Tanah, Pasal 1 angka 1 dan angka 5, Pasal 3, Pasal 6, Pasal 20.

13 Undang-Undang No. 4 Tahun 1996, Pasal 3 ayat (1) menjelaskan bahwa utang yang dijamin pelunasannya dengan Hak Tanggungan dapat berupa utang yang telah ada atau yang telah diperjanjikan dengan jumlah tertentu atau jumlah yang pada saat permohonan eksekusi Hak Tanggungan diajukan dapat ditentukan berdasarkan perjanjian utang-piutang atau perjanjian lain yang menimbulkan hubungan utang-piutang yang bersangkutan. Penjelasan Pasal 3 ayat (1) menjelaskan bahwa utang yang dijamin dengan hak tanggungan dapat berupa utang yang sudah ada maupun yang belum ada tetapi sudah diperjanjikan, misalnya utang yang timbul dari pembayaran yang dilakukan oleh kreditor untuk kepentingan debitor dalam rangka pelaksanaan bank garansi. Jumlahnya pun dapat ditentu-kan secara tetap di dalam perjanjian yang bersangkutan dan dapat pula ditentukan kemudian berdasarkan cara perhitungan yang ditentukan dalam perjanjian yang menimbulkan hubungan utang-piutang yang bersangkutan, misalnya utang bunga atas pinjaman pokok dan ongkos-ongkos lain yang jumlahnya baru dapat ditentukan kemudian. Perjanjian yang dapat menimbulkan hubungan utang-piutang dapat berupa perjanjian pinjam meminjam maupun perjanjian lain, misalnya perjanjian pengelolaan harta kekayaan orang yang belum dewasa atau yang berada di bawah pengampuan, yang diikuti dengan pemberian hak tanggungan oleh pihak pengelola. Pasal 10 ayat (1) menjelaskan bahwa pemberian hak tanggungan didahului dengan janji untuk memberikan hak tanggungan sebagai jaminan pelunasan utang tertentu, yang dituangkan di dalam dan merupakan bagian tak terpisahkan dari perjanjian utang-piutang yang bersangkutan atau perjanjian lain-nya yang menimbulkan utang tersebut. Penjelasan Pasal 10 ayat (1) menjelaskan bahwa sesuai dengan sifat accessoir dari hak tanggungan, pemberiannya harus merupakan ikutan dari perjanjian pokok, yaitu 
jelas bahwa hak tanggungan sebagai aksesoris dari perjanjian pokoknya yang berupa perjanjian pinjam meminjam atau dari perjanjian pokoknya yang berupa perjanjian lain. ${ }^{14}$

Konsep ratio legis pada jaminan fidusia sebagaimana yang telah dituangkan pada UndangUndang Jaminan Fidusia menjelaskan bahwa jaminan fidusia adalah hak jaminan atas benda bergerak dan benda tidak bergerak yang tidak dapat dibebani hak tanggungan, sebagai agunan bagi pelunasan utang tertentu, yang mengutamakan pemegang hak fidusia daripada kreditor lainnya. Jaminan fidusia dapat berlaku untuk setiap perjanjian yang bertujuan membebankan jaminan fidusia. Jaminan fidusia merupakan perjanjian ikutan atau aksesoris dari perjanjian pokok yang menimbulkan kewajiban untuk memenuhinya. Apabila pemberi jaminan fidusia ingkar janji, maka penerima jaminan fidusia mempunyai hak untuk melakukan eksekusi obyek jaminan fidusia untuk mengambil pelunasan utang dari pemberi jaminan fidusia dari hasil penjualan obyek jaminan fidusia dengan menjual objek jaminan fidusia melalui pelelangan umum atau penjualan melalui bantuan pengadilan, atau pemegang jaminan fidusia melakukan penjualan dengan cara di bawah tangan yang dilakukan berdasarkan kesepakatan pemberi dan penerima fidusia. Apabila hasil penjualan obyek jaminan fidusia melebihi nilai penjaminan maka pemberi jaminan fidusia berhak memperoleh sisa penjualannya, dan apabila hasil penjualannya tidak mencukupi nilai penjaminan maka pemberi jaminan fidusia tetap berkewajiban melunasi utang yang belum terbayar dari hasil penjualan obyek jaminan fidusia. Jaminan fidusia sebatas untuk penjaminan pelunasan dan penerima jaminan fidusia tidak dimaksudkan untuk dimiliki oleh penerima jaminan fidusia apabila pemberi jaminan fidusia ingkar janji, akan tetapi penerima jaminan fidusia tidak dilarang menjadi pembeli obyek jaminan fidusia. ${ }^{15}$

Jaminan fidusia untuk menjamin pelunasan utang tertentu yang timbul dari perjanjian. Utang yang dimaksud adalah kewajiban yang dinyatakan dalam jumlah uang baik secara langsung atau tidak langsung. Perjanjian yang dimaksud adalah perjanjian pokok yang menimbulkan kewajiban untuk memenuhi prestasi/kewajibannya, sebagaimana yang telah dituangkan pada Undang-Undang Jaminan Fidusia secara khsusus pada Pasal 4 dan Pasal 7 beserta penjelasannya. ${ }^{16}$

perjanjian yang menimbulkan hubungan hukum utang piutang yang dijamin pelunasannya. Perjanjian yang menimbul-kan hubungan utang-piutang ini dapat dibuat dengan akta di bawah tangan atau harus dibuat dengan akta otentik, tergantung pada ketentuan hukum yang mengatur materi perjanjian itu. Dalam hal hubungan utang-piutang itu timbul dari perjanjian utang-piutang atau perjanjian kredit, perjanjian tersebut dapat dibuat di dalam maupun di luar negeri dan pihak-pihak yang bersangkutan dapat orang perseorangan atau badan hukum asing sepanjang kredit yang bersangkutan dipergunakan untuk kepentingan pembangunan di wilayah negara Republik Indonesia.

${ }^{14}$ Mahkamah Konstitusi RI, Putusan Pengujian Undang-Undang, PUU No. 21/PUU-XVIII/2020 tanggal 27 Agustus 2020, angka 3.11.2 halaman 31-32 menjelaskan bahwa hak tanggungan menurut sifatnya juga merupakan perjanjian ikutan atau accessoir pada suatu piutang tertentu, yang didasarkan pada suatu perjanjian utang-piutang atau perjanjian lain, maka kelahiran dan keberadaannya ditentukan oleh adanya piutang yang dijamin pelunasannya. Demikian juga hak tanggungan menjadi hapus karena hukum, apabila karena pelunasan atau sebab-sebab lain, piutang yang dijaminnya menjadi hapus. Salah satu ciri hak tanggungan adalah mudah dan pasti dalam pelaksanaan eksekusinya jika debitor cidera janji.

15 Undang-Undang No. 42 Tahun 1999, Pasal 1 angka 2, Pasal 2, Pasal 4, Pasal 29, Pasal 33, Pasal 34.

16 Undang-Undang No. 42 Tahun 1999, Pasal 1 angka 7 menjelaskan bahwa utang adalah kewajiban yang dinyatakan atau dapat dinyatakan dalam jumlah uang baik dalam mata uang Indonesia atau mata uang lainnya, baik secara langsung maupun kontinjen. Pasal 4 menjelaskan bahwa jaminan fidusia merupakan perjanjian ikutan dari suatu perjanjian pokok yang menimbulkan kewajiban bagi para pihak untuk memenuhi suatu prestasi. Penjelasan Pasal 4 menjelaskan bahwa yang dimaksud dengan "prestasi" dalam ketentuan ini adalah memberikan sesuatu, berbuat sesuatu, atau tidak berbuat sesuatu, yang dapat dinilai dengan uang. Pasal 7 huruf c menjelaskan bahwa utang yang pelunasannya dijamin dengan fidusia dapat berupa: utang yang pada saat eksekusi dapat ditentukan jumlahnya berdasarkan perjanjian pokok yang menimbulkan kewajiban memenuhi suatu prestasi. Penjelasan Pasal 7 huruf c menjelaskan bahwa utang yang dimaksud dalam ketentuan ini adalah utang bunga atas pinjaman pokok dan biaya lainnya yang jumlahnya dapat ditentukan kemudian. 
Pada transaksi murabahah, bank syariah dapat meminta nasabah sebagai penerima fasilitas pembiayaan untuk memberikan agunan sebagai jaminan tambahan baik berupa benda bergerak maupun benda tidak bergerak yang diserahkan oleh pemilik agunan untuk menjamin pelunasan kewajiban Nasabah Penerima Fasilitas. ${ }^{17}$ Uang muka juga dapat dikategorikan sebagai bagian dari agunan agar nasabah serius pada pembelian aset murabahah sebelum akad disepakati. ${ }^{18}$

Hutang nasabah kepada bank syariah sebesar biaya yang diberikan oleh bank dan keuntungan bank, sehingga pencatatan pada bank adalah piutang murabahah dan pendapatan keuntungan murabahah. Bank syariah menerbitkan surat pengakuan utang bagi nasabah sebagai antisipasi pembuktian bahwa nasabah menerima pembiayaan dari bank. Surat pengakuan utang sebagai penerima pembayaran kewajiban dari nasabah. ${ }^{19}$

Bank dapat membeli sebagian atau seluruh agunan apabila nasabah tidak memenuhi kewajibannya dalam waktu tertentu. Pembelian dapat dilakukan melalui pelelangan umum ataupun di luar pelelangan umum. Bank dengan tetap memperhitungkan nilai kewajiban nasabah yang belum terbayar, yaitu mengembalikan selisih nilai penjualan dengan kewajiban nasabah yang belum terbayar atau dengan nasabah tetap harus memenuhi kekurangan dari nilai penjualan agunan apabila hasil penjualan agunan tidak memenuhi seluruh kewajiban nasabah. ${ }^{20}$

Pengikatan agunan atas dasar surat pengakuan utang dapat mengakibatkan akad murabahah menjadi akad pinjam meminjam, meskipun kewajiban pelunasan nasabah atas pembelian barang dari bank syariah dengan cara murabahah menimbulkan utang bagi nasabah, namun utang nasabah tersebut adalah akibat adanya pembiayaan murabahah dan utang tersebut tidak sebagai akad pokok. Sedangkan utang yang dilengkapi dengan surat pengakuan utang pada pada penyaluran pinjam meminjam adalah akad pokok.

Utang pada pinjam meminjam timbul karena pelunasan utang yang tidak ada jual beli barang, sedangkan utang pada pembiayaan murabahah timbul karena pelunasan pembayaran karena adanya jual beli barang. Akibat dari utang pada pinjam meminjam jika terjadi wanprestasi adalah menjual obyek agunan sebagai pelunasan utang, sedangkan akibat dari utang pada pembiayaan murabahah jika terjadi wanprestasi dapat dengan pembatalan akad jual beli yang diikuti pembayaran ganti rugi.

Terdapat perbedaan antara fatwa DSN MUI tentang jual beli dengan fatwa tentang utang piutang. Utang piutang tidak dibolehkan ada penambahan pada pengembalian di bank syariah, sedangkan jual beli terdapat keuntungan yang dibolehkan bagi bank syariah.

Pemaksaan pencatatan penerbitan surat pengakuan utang bagi nasabah sebagai antisipasi pembuktian bahwa nasabah menerima pembiayaan dari bank, telah menggeser dari jual beli menjadi utang piutang karena tidak ada bukti adanya peralihan kepemilikan bagi bank syariah selaku pembeli dari pemasok untuk dijual kepada nasabah melainkan yang ada yaitu pengakuan utang dari nasabah yang ditujukan kepada bank syariah sejumlah tertentu yang merupakan yang merupakan jumlah dari nilai pembiayaan ditambah keuntungan bagi bank syariah.

\footnotetext{
17 Mahkamah Agung RI, Peraturan Mahkamah Agung Nomor 014 Tahun 2016 tentang Kompilasi Hukum Ekonomi Syariah, Pasal 127.

18 Otoritas Jasa Keuangan RI, “Surat Edaran Produk Dan Aktivitas Bank Umum Syariah Dan Unit Usaha Syariah”, dan "Surat Edaran Produk Dan Aktivitas Bank Pembiayaan Rakyat Syariah”, Lampiran IV, bagian pembiayaan murabahah.

19 Otoritas Jasa Keuangan RI, "Standar Produk Perbankan Syariah Murabahah", 39, 46, dan 81.

20 Undang-Undang No. 21 Tahun 2008 tentang Perbankan Syariah, Pasal 1 angka 26 dan Pasal 40.
} 
Dengan demikian pada dasar ratio legis khususnya pada Undang-Undang Hak Tanggungan dan Undang-Undang Jaminan Fidusia dapat disimpulkan telah mengakomodir perjanjian pembiayaan perbankan syariah khususnya transaksi murabahah yang merupakan transaksi jual beli, yang dapat dikategorikan sebagai perjanjian lain yang menimbulkan kewajiban untuk melunasi pembayarannya, selain perjanjian utang piutang yang menimbulkan kewajiban untuk melunasi utang yang belum melunasi pengembalian utangnya.

Hak tanggungan dan/atau jaminan fidusia seharusnya tetap diposisikan sebagai aksesoris dari adanya perjanjian pokok yang dalam hal ini khususnya pembiayaan murabahah tidak dalam kapasitas membenarkan atau tidak membenarkan adanya pelaksanaan jual beli pada pembiayaan murabahah, melainkan hak tanggungan dan/atau jaminan fidusia sebagai aksesoris adanya jual beli murabahah, yaitu jaminan didasarkan atas jual beli murabahah yang menimbulkan kewajinan nasabah untuk melunasinya, dengan tetap mewajibabkan bank syariah membeli dahulu dari pemasok atas nama bank sendiri sendiri sehingga bank syariah baru dapat bertindak sebagai penjual kepada nasabah dan timbul-lah hak tanggungan dan/atau jaminan fidusia untuk menjamin pelunasan nasabah. Jika Hak tanggungan dan/atau jaminan fidusia dipaksakan dengan keadaan untuk menjamin pelunasan utang nasabah dan utang timbul karena adanya perjanjian pokoknya, maka yang terjadi adalah pinjam meminjam antara bank dengan nasabah sebagai transaksi jasa dan tidak terjadi transaksi murabahah yang merupakan transaksi jual beli antara bank dengan nasabah.

Adanya klausul utang pada Fatwa DSN MUI tentang Murabahah tidak seharusnya dimaknai sebagai perjanjian pokok antara bank dengan nasabah, melainkan utang sebagai aksesoris yang timbul dari adanya transaksi murabahah antara bank dengan nasabah, sehingga hak tanggungan dan/atau jaminan fidusia tidak bisa mendasarkan adanya klausul pada Fatwa DSN MUI melainkan hak tanggungan dan/atau jaminan fidusia harus mendasarkan transaksi obyek murabahah yang menimbulkan kewajiban bagi nasabah untuk melunasi seluruh pembayarannya kepada bank.

\section{Ruang Lingkup Yuridis Empiris}

Pemecahan isu hukum terkait pengikatan agunan perlu dilihat juga pada pelaksanaan kepatuhan terhadap norma-norma hukum. Bank dapat meminta agunan tunai berupa giro atau tabungan atau deposito atau agunan lainnya untuk menjamin kerugian bank syariah yang timbul akibat nasabah membatalkan pemesanannya, sedangkan jaminan pokok yang dapat dipegang oleh bank adalah keyakinan bank terhadap nasabah untuk melunasi kewajibannya sesuai yang dijanjikan. Agunan merupakan perwujudan dari upaya kehati-hatian bagi bank dalam mengelola dana, dan agunan baru dapat dicairkan apabila nasabah telah terbukti melakukan pelanggaran atas kesepakatan yang telah disepakati. Bank boleh menerbitkan surat pengakuan utang (grosse akta) terkait perjanjian murabahah. ${ }^{21}$ Pengikatan agunan untuk pembiayaan murabahah dan pembiayaan ijarah merupakan perjanjian tambahan (aksesoris) dari perjanjian pokoknya yaitu perjanjian/akta pembiayaan murabahah. ${ }^{22}$

Memperhatikan istilah jaminan dari kata "zekerheid" yang mempunyai maksud untuk jaminan dan dari kata "zekerheidsrecht" yang mempunyai maksud untuk hukum jaminan atau hak jaminan. ${ }^{23}$

${ }_{21}$ Otoritas Jasa Keuangan RI, Standar Produk Perbankan Syariah Murabahah (Jakarta: OJK, 2016) 50 dan 45.

22 Otoritas Jasa Keuangan RI, Laporan Perkembangan Keuangan Syariah Indonesia tahun 2017 (Jakarta: OJK, 2018), 229 dan 231.

${ }^{23}$ Frieda Husni Hasbullah, Hukum Kebendaan Perdata: Hak-Hak Yang Memberikan Jaminan Jilid II (Jakarta: Ind-Hill Co, 2005$), 5$. 
Jaminan menurut Hartono Hadisaputro yaitu sesuatu yang diberikan oleh debitur kepada kreditur yang dapat dinilai dengan uang untuk menimbulkan keyakinan bahwa debitur akan memenuhi kewajibannya. ${ }^{24}$ Konsep fiducia cum creditore yaitu seorang debitur menyerahkan suatu barang kepada kreditur, dan kreditur memiliki kewajiban untuk mengembalikan barang itu kepada debitur apabila debitur sudah memenuhi kewajibannya kepada kreditur. ${ }^{25}$

Konsep pengikatan agunan bukan hanya karena utang melainkan dapat juga terjadi karena jual beli yang belum lunas sebagaimana berpedoman pada yurisprudensi atas putusan Mahkamah Agung Belanda (bier brouwerij arrest) pada tingkat kasasi yang menguatkan putusan tingkat banding (hooggerechtshof) yang menyatakan bahwa jual beli dengan hak membeli kembali tersebut dianggap sah. Jual beli dengan hak membeli kembali dapat diartikan sebagai perjanjian penyerahan hak milik secara kepercayaan dan pemberi uang diperbolehkan memiliki benda yang dijadikan objek agunan dalam hal penerima uang wanprestasi. ${ }^{26}$

Pelaksanaan pengikatan agunan sudah seharusnya mengikuti landasan filosofis, ontologis dan ratio legis yang sudah diatur sebagaimana uraian di atas, sehingga pelaksanaan kepatuhan terhadap normanorma hukum pembiayaan murabahah tetap konsisten dalam sistem jual beli. Kepatuhan terhadap prinsip syariah yang sudah diatur didalam suatu aturan hukum seharusnya diimplementasikan dengan mengikuti ketentuan yang sudah ada dan bukan sebaliknya. Jika pelaksanaan hukum mengikuti hukum yang tidak sesuai dengan prinsip syariah padahal kegiatan tersebut seharusnya mengikuti prinsip syariah yang di antaranya dengan memposisikan pengikatan agunan dengan hak tanggungan/jaminan fidusia sebagai aksesoris adanya pembiayaan murabahah dan pengikatan agunan untuk menjamin pelunasan kewajiban nasabah yang belum lunas. Pengikatan agunan tidak seharusnya dimaknai sebagai agunan untuk menjamin pelunasan utang yang timbul dari transaksi pembiayaan murabahah, karena maksud adanya kalimat pelunasan utang adalah sebagai perjanjian pokok yaitu perjanjian utang piutang dan telah menjadikan penyebab pembiayaan murabahah bergeser dari transaksi jual beli menjadi transaksi jasa. Selain itu, pengikatan agunan yang dibuat karena utang piutang atau pengakuan utang, maka akan menimbulkan masalah dan ketidakadilan bagi perbankan khususnya perbankan syariah serta penyelewengan terhadap prinsip syariah atas penyaluran pembiayaan murabahah.

Ketentuan agunan pada Undang-Undang Perbankan Syariah Nomor 21 Tahun 2008 tidak menyinggung keterkaitannya dengan Undang-Undang Hak Tanggungan (Nomor 4 Tahun 1996) dan/ atau Undang-Undang Jaminan Fidusia (Nomor 42 Tahun 1999), sehingga dapat ditafsirkan bahwa agunan pada perbankan syariah harus diatur tersendiri dan terbebas dari aturan hukum UndangUndang Hak Tanggungan dan/atau Undang-Undang Jaminan Fidusia.

\section{Solusi}

Sebagaimana uraian di atas bahwa pengikatan agunan yang digunakan pada pembiayaan murabahah adalah jaminan fidusia atau pemberian hak tanggungan karena utang piutang atau pengakuan utang, dapat dijadikan sebagai antitesis atau das sein. Konsep pembiayaan murabahah dihubungkan dengan teori hukum pengikatan agunan, maka pengikatan agunan seharusnya

\footnotetext{
${ }^{24}$ Hartono Hadisaputro, Pokok-Pokok Hukum Perikatan dan Hukum Jaminan (Yogyakarta: Liberty, 1984), 10.

25 Oey Hoey Tiong, Fidusia Sebagai Jaminan Unsur-Unsur Perikatan (Jakarta: Ghalia, 1985), 35.

26 Mahkamah Agung (Hoge Raad) Belanda, Putusan Bier Brouwerij Arrest, tanggal 25 Januari 1929, N.J. 1929, 616.
} 
didasarkan atas pembiayaan murabahah yang menimbulkan kewajiban bagi nasabah untuk melunasi fasilitas pembiayaan yang belum lunas berdasarkan aturan hukum sendiri yang terbebas dari aturan hukum Undang-Undang Hak Tanggungan dan/atau Undang-Undang Jaminan Fidusia, dapat dijadikan sebagai tesis atau sebagai das sollen.

Pertentangan antara antitesis atau das sein dengan tesis atau das sollen dapat dimunculkan sintesis atau das sollen sebagai saran atau preskripsi yang merupakan jawaban atau kesimpulan, yang diharapkan menjadi satu hal yang utuh dari hasil ilmiah yang baru dan lebih ideal yaitu pengikatan agunan dapat dilakaukan dengan hak tanggungan atau jaminan fidusia, yaitu pengikatan agunan khususnya pada pembiayaan murabahah yang menimbulkan kewajiban bagi nasabah untuk melunasi atas fasilitas pembiayaan yang belum lunas, pengikatan agunan dilakukan dengan nilai sisa pokok pembiayaan setelah dikurangi uang muka, ditambah keuntungan bank syariah, dan biaya lain yang akan timbul pada pelaksanaan eksekusi agunan, dengan hak istimewa bagi bank untuk membeli obyek agunan atau menjual obyek agunan berdasarkan pemberian kuasa untuk menjual dalam hal pembayaran nasabah telah dikategorikan macet atau melakukan wanprestasi/ingkar janji dalam waktu tertentu.

Sebagai contoh bank syariah membeli barang dari pemasok sebesar Rp.95.000.000,00, dan biaya lain yang dikeluarkan oleh bank syariah dengan sejumlah Rp.5.000.000,00, sehingga total seluruhnya yang telah dikeluarkan bank syariah sebesar Rp.100.000.000,00, kemudian dilakukan jual beli murabahah kepada nasabah harga Rp.130.000.000,00, dan nasabah membayar uang muka sebesar Rp.20.000.000,00, maka agunan dibebankan atas pembiayaan murabahah berdasarkan akad nomor xxx dengan nilai kewajiban pokok nasabah yang belum lunas sebesar Rp.80.000.000,00, (100.000.000 - 20.000.000), ditambah keuntungan bank syariah sebesar Rp.30.000.000,00, dan biaya lain yang akan timbul pada pelaksanaan eksekusi agunan, dengan hak istimewa bagi bank syariah untuk membeli obyek agunan atau menjual obyek agunan berdasarkan pemberian kuasa untuk menjual dalam hal pembayaran telah dikategorikan macet.

Pijakan saran ini sebagaimana berpedoman pada asas hukum/doktrin hukum lex posterior derogat legi priori, maka ketentuan Undang-Undang Hak Tanggungan yang diundangkan pada tahun 1996 dan ketentuan Undang-Undang Jaminan Fidusia yang diundangkan tahun 1999 yang hingga kini belum terdapat pembaharuan, dan terdapat aturan pengikatan agunan yang lebih baru yaitu pada perubahan Undang-Undang Perbankan yang diundangkan pada tahun 1998 dan pada UndangUndang Perbankan Syariah yang diundangkan pada tahun 2008 yang memberikan aturan tambahan tentang pengikatan agunan, maka ketentuan pengikatan agunan khususnya untuk pembiayaan murabahah dapat dijamin dengan menggunakan pengikatan hak tanggungan atau jaminan fidusia dengan pembaharuan norma berpedoman pada Undang-Undang Perbankan dan pada UndangUndang Perbankan Syariah.

Sebagaimana berpedoman pada asas hukum/doktrin hukum lex specialis derogat legi generalis, maka ketentuan pada Undang-Undang Perbankan dan pada Undang-Undang Perbankan Syariah yang mengatur secara khusus terkait agunan, pembiayaan murabahah dapat dijamin dengan pengikatan hak tanggungan atau jaminan fidusia dengan pembaharuan norma berpedoman pada Undang-Undang Perbankan dan pada Undang-Undang Perbankan Syariah.

Untuk itu, Undang-Undang Hak Tanggungan dan Undang-Undang Jaminan Fidusia perlu dilakukan review untuk mengakomodir transaksi pembiayaan pada bank syariah khususnya 
murabahah, untuk menjamin kewajiban nasabah untuk melunasi atas fasilitas pembiayaan yang belum lunas dan mengakomodir hak istimewa bagi bank syariah untuk membeli obyek agunan atau menjual obyek agunan berdasarkan pemberian kuasa untuk menjual dalam hal pembayaran telah dikategorikan macet. Dapat juga dilakukan review pada Pasal 69 Undang-Undang Perbankan Syariah dengan menambahkan klausul kedudukan Undang-Undang Hak Tanggungan dan Undang-Undang Jaminan Fidusia telah mengakomodir kedudukan agunan sebagaimana yang dimaksud pada pada Pasal 1 angka 26 dan Pasal 40.

Isu hukum pergeseran dari transaksi jual beli menjadi transaksi jasa karena pengikatan agunan dapat terhapus dengan mendasarkan pengikatan agunan untuk menjamin pelunasan kewajiban nasabah sebagai penerima fasilitas pembiayaan yang belum lunas, sehingga pengikatan agunan dengan hak tanggungan atau jaminan fidusia memenuhi kriteria sebagai aksesoris dari perjanjian pokoknya yaitu transaksi jual beli murabahah. ${ }^{27}$

Strengths (kekuatan) atas solusi yang diuraikan di atas Adanya klausul pengikatan agunan pada Undang-Undang Perbankan Syariah, yang dapat dianggap sebagai pelaksanaan dari asas lex specialis derogat legi generalis, dari Undang-Undang Hak Tanggungan dan Undang-Undang Jaminan Fidusia. Namun Weaknesses (kelemahan) atas solusi yang diuraikan di atas masih terdapat Norma UndangUndang Hak Tanggungan dan Jaminan Fidusia masih identik dengan pengikatan agunan terbatas atas dasar utang karena pinjam meminjam.

Opportunities (peluang) atas solusi yang diuraikan di atas yaitu Otoritas Jasa Keuangan Republik Indonesia (OJK) telah mencanangkan untuk memperkuat dan melakukan harmonisasi aturan-aturan yang menghambat pertumbuhan perbankan syariah dan industri keuangan syariah. Kementerian PPN/Bappenas Republik Indonesia telah merekomendasikan pembaharuan aturan-aturan yang menghambat pertumbuhan keuangan syariah dan akan melakukan evaluasi semua peraturan yang berpotensi menghambat pertumbuhan market share perbankan syariah. Komite Nasional Keuangan Syariah Republik Indonesia (KNKS) yang telah berganti nama menjadi KNEKS (Komite Nasional Ekonomi Keuangan Syariah Republik Indonesia) telah memiliki program quick wins untuk melakukan harmonisasi peraturan perundang-undangan di sektor keuangan syariah. Mahkamah Agung Republik Indonesia, OJK, Bank Indonesia atau instansi lainya dalam kedudukannya sebagai lembaga yang berwenang membuat aturan khususnya terkait pengikatan agunan dapat membuat suatu aturan untuk mengisi kekosongan hukum. ${ }^{28}$ Namun Threats (ancaman) atas solusi yang diuraikan di atas dalam hal perubahan undang-undang, membutuhkan waktu yang cukup panjang, perlu dorongan stakeholder. Perubahan undang-undang bisa dilaksanakan dengan cara yudisial review (pengujian undang-undang terhadap Undang-Undang Dasar Republik Indonesia tahun 1945 beserta perubahannya) oleh Mahkamah Konstitusi Republik Indonesia yang secara terbatas, atau dengan cara legislatif review oleh Dewan Perwakilan Rakyat Republik Indonesia yang mempunyai kewenangan untuk merubah undang-undang, atau dengan cara executiv review oleh Presiden Republik Indonesia dalam hal terdapat kegentingan yang memaksa berupa penerbitan peraturan pemerintah pengganti undang-undang. ${ }^{29}$

\footnotetext{
27 Undang-UndangNo. 21 Tahun 2008, Pasal 1 angka 26.

28 Undang-Undang No. 12 Tahun 2011 tentang Pembentukan Peraturan Perundang-Undangan, Pasal 8.

${ }^{29}$ Undang-Undang No. 12 Tahun 2011, Pasal 9 ayat (1), Pasal 95A, Pasal 95B, Pasal 1 angka 4, Pasal 11, Pasal 52, Pasal 53, lihat pula pada Pasal 22, Pasal 24C ayat (1) Undang-Undang Dasar Tahun 1945, lihat pula pada Badan Pembinaan Hukum Nasional Kementerian Hukum Dan Hak Asasi Manusia RI, Naskah Akademik Rancangan Undang-Undang
} 


\section{Penutup}

Pengikatan agunan dalam kedudukannya sebagai aksesoris dari pembiayaan murabahah seharusnya didasarkan adanya kewajiban nasabah atas pembelian yang belum lunas sebagaimana berpedoman pada Undang-Undang Perbankan Syariah, yang dimaksudkan agar tidak terjadi pergeseran dari transaksi murabahah yang sebagai perjanjian pokoknya menganut sistem jual beli bergeser menjadi transaksi jasa sebagai akibat pengikatan agunan yang mendasarkan utang sebagai perwujudan dari perjanjian pokoknya berupa utang piutang.

Pemenuhan pelaksanaan pembiayaan murabahah agar konsistem pada sistem transaksi jual beli dan menghindari pergeseran dari transaksi jual beli menjadi transaksi jasa, di antaranya bank syariah seharusnya bersikap dan memposisikan pengaturan Undang-Undang Hak Tanggungan dan Undang-Undang Jaminan Fidusia telah ditambahkan normanya pada Undang-Undang Perbankan Syariah Pasal 1 angka 26, Pasal 40 yang mengakomodir adanya agunan untuk menjamin pelunasan pembayaran dari nasabah sebagai kewajiban yang timbul karena penerimaan fasilitas pembiayaan murabahah, sehingga dalam pengikatan hak tanggungan atau pengikatan jaminan fidusia menguraikan atau mencatatkan klausul untuk menjamin pembiayaan murabahah yang menimbulkan kewajiban bagi nasabah untuk melunasi atas fasilitas pembiayaan yang belum lunas dengan nilai sisa pokok pembiayaan setelah dikurangi uang muka, ditambah keuntungan bank syariah, dan biaya lain yang akan timbul pada pelaksanaan eksekusi agunan, dengan hak istimewa bagi bank syariah untuk membeli obyek agunan atau menjual obyek agunan berdasarkan pemberian kuasa untuk menjual dalam hal pembayaran telah dikategorikan macet.

Perlunya melakukan review terhadap Undang-Undang Jaminan khususnya Undang-Undang Hak Tanggungan dan Undang-Undang Jaminan Fidusia atau melakukan review terhadap UndangUndang Perbankan Syariah khususnya pada klausul agunan.

\section{Daftar Pustaka}

Asshiddiqie, Jimly. Hak Menguji (Toetsingsrecht) yang Dimiliki Hakim dalam Sistem Hukum Indonesia. Jakarta: Raja Grafindo Persada, 2006.

Azis, Abdul, Moch. Bukhori Muslim, Nur Hidayah. “Akad Wakalah Menjadi Penyebab Pembiayaan Murabahah Bergeser dari Transaksi Jual Beli Menjadi Transaksi Jasa”. Jurnal Kordinat, Vol 19, No. 2, tahun 2020.

Azis, Abdul, Moch. Bukhori Muslim, Nur Hidayah. "Pembiayaan Murabahah dalam Sistem Transaksi Jual Beli Menurut Fatwa DSN MUI dan KHES, atau UU PPN”. Jurnal Istinbath, Vol 20, No. 1 Tahun 2021.

Azis, Abdul, Moch. Bukhori Muslim, Nur Hidayah. Transaksi Murabahah Perbankan Syariah - Terbelenggu Isu Batal Demi Hukum, Jakarta: IF \& Rekan, 2020.

Azis, Abdul. “Kepemilikan Bank Syariah Secara Prinsip Atas Obyek Pembiayaan Murabahah”. Tesis. Magister Hukum Ekonomi Syariah, Universitas Islam Negeri Syarif Hidayatullah Jakarta, 2020.

Tentang Perubahan Atas Undang-Undang Nomor 12 Tahun 2011 Tentang Pembentukan Peraturan Perundang-Undangan (Jakarta: BPHN Kemenkumhan RI, 2017), 34, yang mengutip dari Jimly Asshiddiqie, Hak Menguji (Toetsingsrecht)

Yang Dimiliki Hakim Dalam Sistem Hukum Indonesia (Jakarta: Raja Grafindo Persada, 2006). 
Badan Pembinaan Hukum Nasional - Kementerian Hukum dan Hak Asasi Manusia RI, Naskah Akademik Rancangan Undang-Undang Tentang Perubahan Atas Undang-Undang Nomor 12 Tahun 2011 Tentang Pembentukan Peraturan Perundang-Undangan, Jakarta: BPHN Kemenkumhan RI, 2017.

Dewan Syariah Nasional Majelis Ulama Indonesia, Fatwa Murabahah, Fatwa No.04/DSN-MUI/IV/2000. Hadisaputro, Hartono, Pokok-Pokok Hukum Perikatan dan Hukum Jaminan. Yogyakarta: Liberty, 1984.

Hasbullah, Frieda Husni, Hukum Kebendaan Perdata: Hak-Hak Yang Memberikan Jaminan Jilid II, Jakarta: Ind-Hill Co, 2005.

Mahkamah Agung (Hoge Raad) Belanda. Putusan Bier Brouwerij Arrest, tanggal 25 Januari 1929, N.J. 1929, 616.

Mahkamah Agung Republik Indonesia. Peraturan Kompilasi Hukum Ekonomi Syariah, PMA No. 02 Tahun 2008.

Mahkamah Agung Republik Indonesia. Peraturan Tata Cara Penyelesaian Perkara Ekonomi Syariah, PMA No. 014 Tahun 2016.

Mahkamah Agung Republik Indonesia. Surat Edaran Pemberlakuan Rumusan Hasil Rapat Pleno Kamar Mahkamah Agung Tahun 2016 Sebagai Pedoman Pelaksanaan Tugas Bagi Pengadilan, SEMA No. 4 Tahun 2016.

Mahkamah Konstitusi Republik Indonesia. Putusan Pengujian Undang-Undang, PUU No. 18/PUUXVII/2019 tanggal 6 Januari 2020.

Mahkamah Konstitusi Republik Indonesia. Putusan Pengujian Undang-Undang, PUU No. 21/PUUXVIII/2020 tanggal 27 Agustus 2020.

Marzuki, Peter Mahmud. Penelitian Hukum Normatif: Edisi Revisi, Jakarta: Kencana, 2017.

Otoritas Jasa Keuangan RI. Laporan Perkembangan Keuangan Syariah Indonesia tahun 2017, Jakarta: OJK, 2018.

Otoritas Jasa Keuangan RI. Standar Produk Perbankan Syariah Murabahah. Jakarta: OJK, 2016, artikel diakses pada 2 September 2019 dari https://www.ojk.go.id/id/kanal/ syariah/beritadan-kegiatan/publikasi/Documents/Pages/Buku-Standar-Produk-Perbankan-SyariahMurabahah/ Buku\%20Standar\%20Produk\%20Murabahah.pdf.

Otoritas Jasa Keuangan RI. Surat Edaran Produk Dan Aktivitas Bank Umum Syariah Dan Unit Usaha Syariah, SEOJK No.36/SEOJK.03/2015.

Otoritas Jasa Keuangan RI. Surat Edaran Produk Dan Aktivitas Bank Pembiayaan Rakyat Syariah, SEOJK No.37/SEOJK.03/2015.

PT BPRS Puduarta Insani. Jual Beli Murabahah, 10 Oktober 2018, dari http://ptbprspuduartainsani. com/halaman /jual-beli-murabahah.

Tiong, Oey Hoey. Fidusia Sebagai Jaminan Unsur-Unsur Perikatan, (Jakarta: Ghalia, 1985.

Undang-Undang Nomor 12 Tahun 2011 tentang Pembentukan Peraturan Perundang-Undangan, LN No. 82 Tahun 2011, TLN No.5234 Juncto UU No. 15 Tahun 2019, LN No. 183 Tahun 2019, TLN No. 6398.

Undang-Undang Nomor 21 Tahun 2008 tentang Perbankan Syariah, LN No. 95 Tahun 2008, TLN No. 4867. 
Undang-Undang Nomor 4 Tahun 1996 tentang Hak Tanggungan Atas Tanah Beserta Benda-Benda Yang Berkaitan Dengan Tanah, LN No.42 Tahun 1996, TLN No. 3632.

Undang-Undang Nomor 42 Tahun 1999 tentang Jaminan Fidusia, LN No. 168 Tahun 1999, TLN No. 3889.

Wawancara dengan Hamza Marasabessy, Karyawan BNI Syariah Ambon, 8 April 2020 melalui media whatsapp.

Wawancara dengan Rudi Widodo, Kepala Sub Bagian Pengembangan Perbankan Syariah Sektor Jasa Keuangan Otoritas Jasa Keuangan RI, 15 Juli 2020 melalui media telepon. 